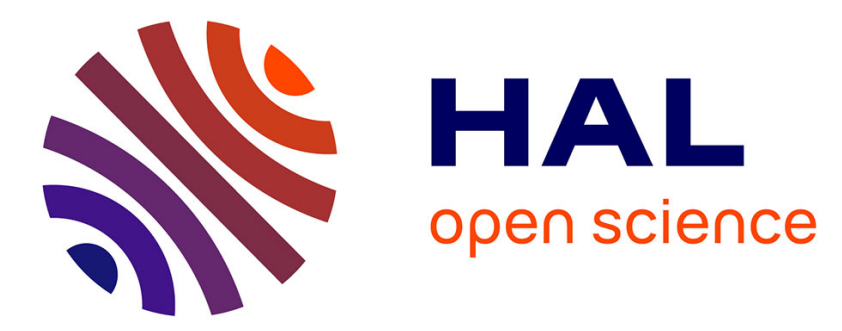

\title{
Environmental risk factors of primary brain tumors: A review
}

\author{
A. Vienne-Jumeau, C. Tafani, D. Ricard
}

\section{To cite this version:}

A. Vienne-Jumeau, C. Tafani, D. Ricard. Environmental risk factors of primary brain tumors: A review. Revue Neurologique, 2019, 175, pp.664 - 678. 10.1016/j.neurol.2019.08.004 . hal-03488519

\section{HAL Id: hal-03488519 \\ https://hal.science/hal-03488519}

Submitted on 21 Dec 2021

HAL is a multi-disciplinary open access archive for the deposit and dissemination of scientific research documents, whether they are published or not. The documents may come from teaching and research institutions in France or abroad, or from public or private research centers.
L'archive ouverte pluridisciplinaire HAL, est destinée au dépôt et à la diffusion de documents scientifiques de niveau recherche, publiés ou non, émanant des établissements d'enseignement et de recherche français ou étrangers, des laboratoires publics ou privés.

\section{다)(1) $(5$}

Distributed under a Creative Commons Attribution - NonCommercial| 4.0 International 


\section{Environmental risk factors of primary brain tumors: a review}

Aliénor VIENNE-JUMEAU ${ }^{1 \S}$, Camille TAFANI ${ }^{2 \S} \mathrm{MD}$, Damien RICARD ${ }^{2,3,1}{ }^{*} \mathrm{MD} \mathrm{PhD}$.

${ }^{1}$ Cognition and Action Group, Cognac-G, CNRS UMR 8257, Université Paris Descartes, Université de Paris, Service de Santé des Armées, 45 rue des Saints Pères, 75006 PARIS, France.

${ }^{2}$ Service de Neurologie de l'Hôpital d'Instruction des Armées de Percy, Service de Santé des Armées, 101 avenue Henri Barbusse, 92140 CLAMART, France.

${ }^{3}$ Ecole du Val-de-Grâce, Ecole de Santé des Armées, 1 Place Alphonse Laveran, 75005 PARIS, France.

* Corresponding Author: damien.ricard@m4x.org

$\S$ both authors have equally contributed.

Keywords: brain tumor, brain neoplasm, environmental risk factor, environmental exposure 


\section{$\underline{\text { Abstract }}$}

Adult primary tumors of the central nervous system are rare, but the incidence is increased in some European countries. Several environmental exposures have been investigated as potential risk factors, but for most, scientific evidence is still lacking. Here we review studies of environmental factors potentially involved in the carcinogenesis of brain tumors: the potential association between primary central nervous system tumors and ionizing radiation, some toxic agents (N-nitroso compounds, pesticides), air pollution, and radiofrequency electromagnetic waves. Brain-ionizing irradiation, especially during childhood, constitutes a well-established risk factor for brain tumors. Exposure to environmental toxins has been poorly explored and data give inconsistent clues about $\mathrm{N}$-nitroso compounds or pesticides as risk factors of brain tumors even for prenatal exposure. For out-door pollution and risk of brain tumour, results of large prospective studies are contradictory. The effect of mobile phones on the risk of developing brain tumors has not been established for glioma and meningioma in adults, but the link with acoustic neurinoma is becoming robust. The effect of mobile phones has still not been explored in children. 


\section{INTRODUCTION}

Adult primary tumors of the central nervous system (CNS) are rare, with an incidence of 7.0 per 100,000 person-years in Europe [1]. However, they are associated with poor overall prognosis, with a rate of mortality of 5.4 per 100,000 person-years [1]. In children, these tumors are the most frequent solid tumor, inducing significant mortality in this population [2]. In some European countries, there is a trend toward an increase in incidence [3]. Hypotheses for this increase include exposure to exogenous risk factors [3-5]. Several environmental exposures have been investigated as potential risk factors, but for most, scientific evidence is still lacking. To date, the International Agency for Research on Cancer (IARC) has classified only ionizing radiation as an established carcinogen (group 1). Other environmental factors are debated.

The present review focused on environmental factors potentially involved in brain tumor carcinogenesis: studies dealing with the potential association between primary CNS tumors and ionizing radiation, some toxic agents (N-nitroso compounds, pesticides), air pollution, and radiofrequency $(\mathrm{RF})$ electromagnetic waves.

\section{Ionizing radiation}

The role of ionizing radiation as a risk factor for brain tumors, and especially glioma, meningioma and nerve sheath tumors, is well established, especially in patients who underwent brain high-dose radiotherapy for cancer treatment in childhood [6,7]. Moreover, among 10,834 patients receiving low-dose cranial and cervical irradiation for tinea capitis (mean dose to neural tissue: $1.5 \mathrm{~Gy}$ ), the relative risk (RR) of developing a tumor was 6.9; the risk for glioma was 2.6 [8]. CT scans of the head in childhood expose the brain to radiation doses of up to 40 to $50 \mathrm{mGy}$. Also, recent follow-up studies of large cohorts of children and adolescents exposed to diagnostic CT scans of the head have reported an excess RR (ERR) for brain cancer as large as 23 per Gy $[9,10]$. To date, the CT-scan effect has not been demonstrated in adults. Nevertheless, epidemiological studies are less numerous and less powerful in adults. Thus, brain irradiation even at low doses and especially in childhood constitutes a well-established risk of (second) brain tumor.

Fortunately, ionizing radiation is not an usual environmental factor, even though environmental non-iatrogenic ionizing radiation occurred during atomic bomb detonations 
(Hiroshima and Nagasaki), after which a high incidence of certain brain tumors was observed. Shintani et al. reported increased incidence of meningioma in adults as soon as 5 years after the bombing (5 per 100,000), which increased to 15 per 100,000 at 20 years later [11]. The incidence was correlated with the dose of radiation received (evaluated by distance from the hypocenter). For all types of brain tumors, the dose-response relation, measured by ERR per Gy, was greater with exposure at younger ages, as was previously reported for the Life Span Study cohort $[12,13]$.

\section{Toxic}

\subsection{N-nitroso compounds (NOCs)}

Among potential risk factors, NOC exposure has long been suspected as a risk factor of brain tumor [14]. NOCs are potent carcinogens in animal models. They are classified in group 2A (probable carcinogen) by the IARC. NOCs include nitrosamines, which require metabolic activation to a carcinogenic form, and nitrosamides, which do not require activation. Nitrosamines can form endogenously from foods treated with sodium nitrite, and certain foods such as bacon and beer contain pre-formed nitrosamines [15]. Although pre-formed nitrosamine levels in beer and nitrite levels have declined substantially since the 1980s, the small amounts of nitrosamines in food are nonetheless significant because humans may be more sensitive to these carcinogens than laboratory rodents [15].

A long-standing hypothesis in the epidemiology of gliomas is that NOC exposure may increase the risk. The hypothesis that NOCs may be involved in the etiology of brain tumors comes both from observations of animal studies that these compounds may be able to pass through the blood-brain barrier and that such compounds may be highly carcinogenic in animals. The most recent and pertinent studies are presented in Table 1.

Transplacental exposure to ethylnitrosourea, a nitrosamide, results in formation of brain tumors including gliomas in rodents and primates [16]. The addition of vitamin $\mathrm{C}$ to the diet prevents tumor formation in this model. Human NOC exposure is divided equally between exogenous and endogenous sources. Nitrosamines in tobacco (mainly sidestream smoke), cosmetics, automobile interiors, and cured meats are the best-established exogenous (environmental) sources of NOC exposure. Other sources include rubber products (baby 
pacifiers, bottle nipples) and certain drugs including antihistamines, diuretics, oral hypoglycemic agents, antibiotics, tranquilizers, and narcotics. N-Nitrodiethanolamine, a carcinogen in animal models, occurs mainly as a contaminant in cosmetic products, soaps, shampoos, and hand lotions. Some environmental sources may contain both nitrosamines and nitrosamides. The endogenous formation of NOCs is a complex process that occurs in the stomach. It depends on the presence of NOC precursors (i.e., nitrates and nitrites), gastric $\mathrm{pH}$, the presence of bacteria, and other physiological parameters [17].

Measurement of NOC exposure is difficult, given the many exogenous and endogenous sources. Thus, misclassification of exposure is a major limitation for any study on this topic. However, because processed and cured meats are sources of NOC precursors and some preformed nitrosamines, dietary assessment may be a useful surrogate marker for NOC exposure $[18]$.

Epidemiological support for NOC exposure as a risk factor for brain tumors comes mostly from studies of pediatric brain tumors and maternal diet. Several studies have assessed the association between maternal diet and childhood brain tumor risk [19]. A meta-analysis determined that frequent intake of processed meats during pregnancy was associated with an elevated risk of childhood brain tumors (RR 1.68; 95\% confidence interval [CI], 1.30-2.17) [20]. However, the authors of this meta-analysis caution against drawing definitive conclusions because of several study design limitations such as recall and selection bias. A recent international, collaborative, pooled case-control study assessed maternal diet during pregnancy (including cured meat intake) and risk of childhood brain tumors in children of the mothers [21]. It included 9 studies, involving centres from 7 countries. Most of the 1218 cases were diagnosed between 1982 and 1992, and 2223 controls were included. The age of children ranged from 0 to 19 years. Mothers were asked about their food consumption during the past year and during the index pregnancy (i.e., pregnancy with the study participant). The dietary questionnaire focused on foods high in nitrates and/or nitrites and foods containing nitrosation inhibitors (i.e., vitamins $\mathrm{C}$ and E). Dietary consumption was estimated in average grams per day. Cured meat consumption by the mother during pregnancy was associated with increased risk of all brain tumors combined, but particularly astroglial tumors. The multivariable odds ratio (OR) for the top versus bottom quartile of consumption was 1.5 (95\% CI, 1.1-2.1; Ptrend = 0.03) for all brain tumors combined and 1.8 (95\% CI, 1.2-2.6; Ptrend = 0.01) for astroglial tumors. The Working Group concluded that this was an informative study 
because of the large study size, the geographical variation of the pooled studies, and the large number of food items investigated, including cured meats. However, recall bias by mothers could not be excluded.

Case-control studies provide inconsistent results about dietary intake of foods containing preformed nitrosamines or compounds that can be converted to nitrosamines and risk of brain tumour in adults, although a few case-control studies reported strong positive associations [22,23]. The potential for bias in these studies is high. A collaborative, pooled case-control study of cured meat consumption and risk of adult brain tumors [24] did not show an association between cured meat consumption and adult brain tumors. Two large prospective cohort studies examined consumption of meat and foods high in nitrites or nitrates and risk of brain tumour. Michaud et al. (2009) [25] analysed combined data from 3 US prospective cohort studies with 335 adult glioma cases diagnosed during 24 years of follow-up. No associations were observed between consumption of red meat, processed meat, bacon, or hot dogs and risk of glioma. Another large US cohort study of 585 adult glioma cases found no significant trends for glioma risk with consumption of red or processed meat [26]. Data from these 2 large studies, which are less prone to bias than case-control studies, provide little evidence for the NOC hypothesis, at least as it pertains to adult gliomas.

Vitamins $\mathrm{C}$ and $\mathrm{E}$ inhibit nitrosation reactions in vivo, and intake of these vitamins can reduce the endogenous formation of NOCs in the stomach. Epidemiological studies have demonstrated that consumption of vitamin $\mathrm{C}$ reduces the risk of gastric cancer [27], a tumor for which NOCs may be a risk factor [28]. Statistically significant inverse associations with dietary vitamin $\mathrm{C}$ or supplemental intake have been observed in a few case-control studies [29]. Furthermore, no associations were observed in a large prospective cohort study examining intake of vitamins $\mathrm{C}$ and $\mathrm{E}$ and a total antioxidant score and risk of glioma [25]. Currently, evidence does not support a causation for vitamin intake and risk of glioma.

\subsection{Pesticides}

The role of pesticides in CNS tumor risk was first suggested by studies of mortality rates in farmers in the United States and Scandinavia. In fact, farmers globally present a lower risk of cancer than the general population but a higher risk for certain cancer sites, including the CNS. This result was consistent across studies, and confirmed by a review and a meta- 
analysis [30,31]. One study found a statistically significant $30 \%$ increase in risk of brain tumors in farmers. Several risk factors may explain this finding, including exposure to not only pesticides but also viruses, solvents and fertilizers. Arsenicals, which are widely used in vineyards, for potatoes and tree crops, have been classified by the IARC as carcinogenic in humans, whereas non-arsenical insecticides as well as glyphosate, diazinon and malathion used in agriculture have been classified as probably carcinogenic to humans (2A).

Yet, there is no evidence of an association between these agents and brain tumors. Some pesticides are proven carcinogens in animals, so pesticide exposure could play a role in brain tumors. However, data for specific pesticides are lacking owing to the marketing of more than 1000 such molecules in recent decades.

In the literature, several case-control studies and a few cohort studies evaluated the possible association between pesticide exposure and CNS tumors, especially gliomas and meningiomas (Table 2). The results do not all converge. Indeed, some authors report no association, whereas others report increased risk [32] with duration of use [33] or a dose effect [34]. The potential role of agricultural pesticides was evaluated in cohorts of nearly 200000 French farmers [35]. Analyses showed several increased risks of CNS tumors in farmers, especially in pesticide users (hazard ratio $=1.96 ; 95 \%$ confidence interval: 1.113.47). Associations varied with tumor subtypes and kinds of crop and animal farming. The main increases in risk were observed for meningiomas in pig farmers and in farmers growing sunflowers, beets and potatoes and for gliomas in farmers growing grasslands. In most cases, more pronounced risk excesses were observed among pesticide applicators. Even if we cannot completely rule out the contribution of other factors, pesticide exposures could be of primary concern to explain these findings.

Few epidemiological studies have provided a detailed estimation of exposures. For instance, lists of pesticides were suggested in the US Upper Midwest Health Study, with pesticides grouped according to their chemical properties [36]. A recent study showed increased risk of CNS tumors with overall exposure to carbamate insecticides [33]. A French study observed an association between brain tumors and exposure to pesticides in vineyards, but the agents potentially involved could not be identified [37]. 
This is not only a concern for farmers per se. Indeed, in the general population, Carles et al. found a significant association between meningioma and residential proximity to open field crops, but no significant association was found between glioma and residential proximity to agricultural land [38].

Regarding the risk of childhood brain tumors and parental exposure of pesticides, results are inconsistent. A meta-analysis of 16 case-control and five cohort studies found a significantly increased risk (30-50\%) related to occupational exposure to pesticides among mothers during the prenatal period [39]. Another meta-analysis identified residential/domestic exposure to pesticides as a risk factor for childhood brain tumor, particularly for indoor exposure, involving insecticides [40]. Data from 2 French national population-based, case-control studies found childhood brain tumors significantly associated with maternal home use of pesticides during pregnancy (OR 1.4, 95\% CI 1.2-1.8) and more specifically with insecticides (OR 1.4, 1.2-1.8) [41]. In a recent international prospective study, paternal exposure to pesticides and animals was not associated with increased risk of childhood CNS tumors [42]. To date, the small samples and the weakness in exposure quantification in these studies do not allow for accepting the ERR due to parental pesticide exposure.

In general, data on pesticide exposure and brain tumors are inconsistent. Study validity is often questionable, and exposure assessment using biological measures of exposure is mostly lacking. Despite the large number of studies in several occupational settings, an increased risk of brain tumor development based on occupational status is not established. While waiting for more reliable studies, one should proceed with caution with pesticide exposure.

\section{Outdoor air pollution}

Outdoor air pollution is a global public health problem, particularly prevalent in megalopoles and southern countries but also important in developed European countries [43]. It results from multiple sources including transport, industrial activity and power generation, biomass burning, and domestic heating, lighting, and cooking based on solid fuel [44]. Outdoor air varies substantially both in space and time because of the mix of sources and the external effects, including oxidation and weather. 
In 2013, members from the IARC unanimously classified outdoor air pollution as carcinogenic, with a strong causal association with lung cancer in particular [45]. Several diseases of the CNS, including ischemic stroke [46-48] and Parkinson disease, were linked to pollution exposure [49]. Outdoor air pollution comprises several potentially carcinogenic factors: particulate matter (PM), black carbon, heavy metals (e.g., vanadium, nickel, and manganese), environmental tobacco smoke, organic compounds (e.g., polycyclic aromatic hydrocarbons and endotoxins) and gaseous pollutants (e.g., $\mathrm{O}_{3}, \mathrm{NO}_{2}, \mathrm{SO}_{2}, \mathrm{CO}$ ). $\mathrm{PM}$ and $\mathrm{O}_{3}$ are thought to be the 2 most important dangers to public health [50,51].

However, data regarding brain tumors are scarce. In addition to biological and animal models, only a few epidemiological studies exist: 2 ecological studies [52,53], 4 cohort studies [5457] and 1 case-control study [58] (Table 3).

Studies of animals argue for the penetrance of particles and mineral magnetite into the CNS, which causes neuroinflammation [59,60]. Brain inflammation within a tumor microenvironment is thought to increase oxidative stress and DNA damage, thus stimulating both genetic and epigenetic changes that occur during glioma evolution [61].

Conflicting results arise from epidemiological studies. The European Study of Cohorts for Air Pollution Effects [57] reported evidence of an association between traffic-related air pollution, using $\mathrm{PM}_{2.5}$ (PM with a diameter of less than 2.5 micrometers) absorbance as a proxy, and brain tumors. However, McKean-Cowdin et al. and Valberg et al. found a negative association between sulfur dioxide, nitrogen dioxide, and carbon monoxide exposure and nervous system cancer mortality or incidence [52,62]. The authors proposed that the protective effect is induced by chronic immune stimulation. Indeed, immune hyperactivity is characteristic of allergies and asthma, both conditions inversely correlated with brain cancer risk in most studies [63-67] if not all [68]. Another incoherence was found in the Danish population: in a first nationwide cohort study [55], Poulsen et al. identified an exposureresponse linear association between nitrogen oxides at the residence - as a proxy of outdoor pollution - and risk for brain cancer. They found contradicting evidence in another nationwide case-control study [58], where they could not replicate this association. Still, this second study highlighted an increased risk of non-glioma tumours with high exposures (nitrogen oxides concentration $\geq 100 \mu \mathrm{g} / \mathrm{m}^{3}$ ) with an OR of 2.3 (95\% CI 1.2-4.6). 
As a whole, data for the effect of outdoor air pollution on brain cancerogenesis mostly rely on a small number of studies that are exploratory in nature. Thus, to date, we lack evidence to incriminate air pollution in the development of brain tumors.

\section{Radiofrequency electromagnetic waves}

Radiofrequency (RF) radiation is a form of non-ionizing radiation that can be emitted by diverse instruments such as mobile phones and their base stations but also radio and television broadcasting, wireless networks such as Wi-Fi, satellite communications, microwave ovens or radar. The exposure to RF is ubiquitous, but recent research focused principally on mobile phones because they are placed near the head and brain. According to the Global System for Mobile Communications, 5.1 billion people around the world, accounting for $67 \%$ of the global population, subscribed to mobile services by the end of 2018. With this overwhelming increase in cell-phone use, widespread concerns have been raised about the effects of exposure to radiofrequency electromagnetic waves. In fact, there is abundant literature consisting of biological and animal studies, several case-control and cohort studies and a few reviews and meta-analyses on the possible association between mobile phone use and CNS tumors, especially gliomas, meningiomas or nerve sheath tumors (acoustic neuroma in particular).

First, the possible biological carcinogenic effects of exposure of the CNS tissue to RF was studied with cell or animal models. Even though these results could not be applied to humans directly, they provide basic information on the possible underlying phenomenon [69]. According to these studies, long-term exposure to RF triggers molecular changes, inducing cell proliferation or cell death [69-71]. Indeed, modification of signaling occurs because of altered ionic distribution and permeability or membrane fluidity [72]. Modification of neuronal activity was observed [73-75], which may be related to increased temperature $[69,76,77]$. Still, discrepancies between studies exist, depending mainly on protocols (duration, frequency, amplitude of exposures), which warrant further analysis [72].

Nine meta-analyses have been published to study the association between mobile-phone use and brain cancer incidence. Their characteristics are in Table 4. Included brain cancers are of 3 main types: glioma (with a distinction between low-grade and high-grade glioma in some studies only), acoustic neurinoma and meningioma. Their results are partly ambiguous, which 
may be explained by heterogeneity in the selection criteria and the statistical analysis. These meta-analyses are mostly based on studies performed by the Hardell or Interphone group. The Interphone interview-based multicenter case-control study is the largest study to date. It was conducted in 13 countries and included 2708 glioma and 2409 meningioma cases and matched controls [78]. The risk of glioma or meningioma was not increased in the whole population of mobile-phone users. Suggestive evidence was found for increased incidence of glioma but not meningioma, when exposure levels overpassed a certain level. Adjustment for possible bias, performed by another team, did not significantly change the results [79]. The 2 most recent meta-analyses of epidemiological studies were published in 2017. One metaanalysis found a significant association for prolonged exposure ( $\geq 10$ years) and ipsilateral location for all CNS tumors (no difference between glioma, meningioma and acoustic neuroma) and all phone types [80]. The second meta-analysis focused on the risk of mobilephone use on gliomas but found no association when pooling all durations of use but did find an association among long-term users, $\geq 10$ years. Risk of phone use was correlated with lowgrade glioma, particularly for long-term users [81].

The ORs for both these meta-analyses and the other 7 published earlier are shown in Table 5 . As a whole, they converge toward an increased risk for glioma and acoustic neuroma but not meningioma with long-time mobile-phone use ( $\geq 10$ years, with this threshold set arbitrarily) on the side of the tumor. When pooling all durations of use and both sides of the head to compute, results were much more discordant across studies. Indeed, both restrictions to ipsilateral location and long duration of use should be arguments favoring a carcinogenic effect of RF on CNS tissue. Indeed, because RF exposure is localized, tumors should predominate in regions with the highest energy absorption. As discussed by Dimbylow and Mann and later by Cardis et al., more than $90 \%$ of the energy is absorbed in the side of the head the phone is placed close to, with $50 \%$ to $60 \%$ localized in the temporal lobe $[82,83]$. Indeed, some studies report increased risk in the temporal and overlapping lobes [78,84]. The association of mobile-phone use and brain tumors restricted to long duration of use ( $\geq 10$ years in most studies) $[78,84,85]$ argues for a dose-effect with a dependence on cumulative use.

The difference seen between low- and high-grade gliomas was hypothesized to be due to the natural history difference between low- (WHO grade I and II) and high- (WHO grade III and IV) grade gliomas. Indeed, relative to high-grade glioma, especially primary glioblastoma, low-grade gliomas occur at lower ages and have a long latency period [81]. Therefore, these 
two types may involve different carcinogenesis pathways, with different risk factors. A high proportion of grade III gliomas are degenerated low-grade gliomas. However, because they are generally analyzed together with primary glioblastoma, which progresses fast with both a short latency period and disease course, the analysis might overlook the association between mobile-phone use and grade III gliomas [81].

Hardell and Carlberg (2013) evaluated the Bradford Hill criteria for causality between longterm mobile-phone use ( $\geq 10$ years) and brain cancer. The authors concluded that all 9 issues in causation were now fulfilled [86]. On the basis of epidemiological studies, they concluded that the criteria for strength, consistency, specificity, temporality, and biologic gradient were fulfilled for evidence of increased risk for glioma and acoustic neuroma. Biological and animal laboratory studies brought additional evidence for plausibility and analogy. Support for coherence came from data on the incidence of brain tumors, which showed increased incidence of brain tumors, especially in heavily exposed areas. The experiment criterion was supported by 2 observations: first, several studies found antioxidants protective of the generation of reactive oxygen species involved in biologic effects, although a direct mechanism for brain tumor carcinogenesis has not been described. Second, studies involving phones used within cars with fixed antennas showed no increased risk of brain tumors.

Still, limitations of the meta-analyses and the underlying studies are numerous. First, included studies are mostly of limited quality (case-controls, with small group numbers) [44]. Prospective cohorts would address the question more specifically [87], but the low incidence of brain tumors would require a high number of participants, and the long latency would require a long follow-up period. Still, one prospective cohort study found an association between mobile-phone use and acoustic neuroma, although the time from exposure to tumor onset was limited to 10 years [88]. Another concern regards the quantification of exposure level. Indeed, mobile-phone use is difficult to assess precisely because the level of exposure depends on the phone type and generation. For instance, the average output power of calls with the Global System for Mobile Communications and Universal Mobile Telecommunications Service differs by a factor of 100 to 500 [89,90]. Besides, patterns of phone use change over time [91]. In terms of these difficulties, the exposure assessment seems highly insufficient. In cohort studies, the assessment relied on information from operators - a person classified as a user if he/she subscribed to a mobile-phone service — or 
to a vague statement "telephone use likely or certain" $[4,13]$. In case-control studies, interviews allowed for recovering more specific information.

Still, most of the time, evaluations seem largely unsatisfactory in some studies. First, response rates were low, averaging 50\% (45\% in the CERENAT study [92] and 53\% in the Interphone study [78]). Second, in some studies, as in the CERENAT study, regular mobile phone use was defined as use at least once a week for at least 6 months without further difference between an occasional user (once a week) and heavy user (several times a day). Another problem was with the use of Digital Enhanced Cordless Telecommunications cordless phones. Hardell et al. [93,94], Hansson Mild et al. [95] and Morgan et al. [96] pointed out that cordless phone users were wrongly classified as mobile-phone non-users in some studies. Indeed, Hardell et al. mentioned that calls are usually longer with cordless phones than mobile phones [51,52]. Also, latency periods were limited to 2 to 10 years in the first studies, which is too short to be sensitive enough for determining long-term risk [81, 97, 98]. Newer studies tend to include patients with long-term use ( $\geq 10$ years). Another problem is that childhood exposures have been largely unexplored [99-101]. Also, meta-analyses all report substantial between-study heterogeneity and low number of studies for subgroup analysis. Only low adjustment for confounding factors was sometimes possible [81].

On the whole, we have no strong and consistent evidence for a causal relation between RF exposure and CNS tumors, but we have evidence for an association with acoustic neurinoma in long-term users. Nevertheless, studies have many limitations that preclude definitively ruling out the association. Further studies, especially prospective studies, should be performed to further assess whether mobile-phone exposure is associated with brain tumor risk [80,100,102,103]. In 2011, based on the available conflicting scientific evidence, the IARC classified RF in the carcinogenic group 2B, that is, among possible carcinogens [104]. However, for some authors, the evidence is strong enough to support a change in the IARC classification and classify RF as a probable carcinogen (group 2A) [96] or even carcinogen (group 1) [86,105].

\section{CONCLUSION}

To date, the causal factors of brain tumors remain unknown. This unanswered question constitutes an additional disappointing fact for patients and their relatives when they are 
diagnosed with a brain tumor. Moreover, brain tumor incidence is continuously increasing, although slightly, in developed countries. Therefore, identifying the potential causes or risk factors is pressing. Yet, environmental exposure has been poorly explored. The low incidence rates of brain tumors, their appearance probably a long time after exposure, and reliable quantification of the exposure to environmental factors are the main difficulties to overcome to correctly explore potential risk factors. In that regard, prospective studies on long-term effects of a given exposure remain the only way to definitively link a risk factor to brain tumors.

Here we reviewed the literature to evaluate the association between a range of environmental exposures and primary brain tumors. To date, only few environmental exposures have been explored in terms of brain tumor risk. Brain ionizing irradiation, even at low doses, and especially during childhood, constitutes a well-established risk factor of brain tumors and has been an environmental concern in areas subjected to atomic bomb radiation exposure. Few studies exist of environmental toxins, and they give inconsistent conclusions on the role of NOCs or pesticides as brain tumor risk factors, even for prenatal exposure. Out-door pollution with several compounds was incriminated in brain-tumor carcinogenesis. However, results of large prospective studies lasting more than 10 years are contradictory. Still, fine microparticles from pollution, $\mathrm{PM}_{2.5}$, have been incriminated as brain-tumor risk factors in several robust studies. In contrast to toxin studies, many studies have addressed the effect of mobile phones on brain-tumor risk. Despite several ambitious and well-designed international studies, this effect has not been established in adults for glioma and meningioma, but the link with acoustic neurinoma is becoming robust. Besides, the effect of mobile phone use has still not been explored in children.

Based on the available literature and following on a precautionary principle, we can thus make a few recommendations regarding environmental exposures and risk of brain tumours:

- Ionizing radiation : the radiation burden of radiological interventions should be weighted at all ages, and especially in children.

- N-nitroso compounds : pregnant women should limit the consumption of cured meat.

- Pesticides: people, and farmers in particular, should protect themselves during pesticide use.

- Outdoor pollution : national and local strategies to reduce outdoor air pollution should be supported. Individuals can participate in improving air quality levels in their communities by lowering their personal emission of fossil-fuel (eating local food, 
using more sustainable modes of transportation like car-pooling, mass transport, cycling, or walking, using clean and renewable energy, and installing effective insulation in their homes).

- Mobile phones : when not used, mobile phones should be switched off or set to an airplane mode. Hands-free telephones may also be useful. Children, and especially toddlers, should be kept away from their use. 


\section{REFERENCES}

[1] Ferlay J, Colombet M, Soerjomataram I, Dyba T, Randi G, Bettio M, et al. Cancer incidence and mortality patterns in Europe: Estimates for 40 countries and 25 major cancers in 2018. Eur J Cancer Oxf Engl 1990 2018;103:356-87. doi:10.1016/j.ejca.2018.07.005.

[2] McNeill KA. Epidemiology of Brain Tumors. Neurol Clin 2016;34:981-98. doi:10.1016/j.ncl.2016.06.014.

[3] Philips A, Henshaw DL, Lamburn G, O'Carroll MJ. Brain Tumours: Rise in Glioblastoma Multiforme Incidence in England 1995-2015 Suggests an Adverse Environmental or Lifestyle Factor. J Environ Public Health 2018;2018. doi:10.1155/2018/7910754.

[4] Binder-Foucard F, Bossard N, Delafosse P, Belot A, Woronoff A-S, Remontet L, et al. Cancer incidence and mortality in France over the 1980-2012 period: solid tumors. Rev Epidemiol Sante Publique 2014;62:95-108. doi:10.1016/j.respe.2013.11.073.

[5] Baldi I, Gruber A, Alioum A, Berteaud E, Lebailly P, Huchet A, et al. Descriptive epidemiology of CNS tumors in France: results from the Gironde Registry for the period 2000-2007. Neuro-Oncol 2011;13:1370-8. doi:10.1093/neuonc/nor120.

[6] Ron E, Modan B, Boice JD, Alfandary E, Stovall M, Chetrit A, et al. Tumors of the brain and nervous system after radiotherapy in childhood. N Engl J Med 1988;319:1033-9. doi:10.1056/NEJM198810203191601.

[7] Karlsson P, Holmberg E, Lundell M, Mattsson A, Holm LE, Wallgren A. Intracranial tumors after exposure to ionizing radiation during infancy: a pooled analysis of two Swedish cohorts of 28,008 infants with skin hemangioma. Radiat Res 1998;150:357-64.

[8] Shore RE, Albert RE, Pasternack BS. Follow-up study of patients treated by X-ray epilation for Tinea capitis; resurvey of post-treatment illness and mortality experience. Arch Environ Health 1976;31:21-8.

[9] Mathews JD, Forsythe AV, Brady Z, Butler MW, Goergen SK, Byrnes GB, et al. Cancer risk in 680,000 people exposed to computed tomography scans in childhood or adolescence: data linkage study of 11 million Australians. BMJ 2013;346:f2360. doi:10.1136/bmj.f2360.

[10] Pearce MS, Salotti JA, Little MP, McHugh K, Lee C, Kim KP, et al. Radiation exposure from CT scans in childhood and subsequent risk of leukaemia and brain tumours: a retrospective cohort study. Lancet Lond Engl 2012;380:499-505. doi:10.1016/S01406736(12)60815-0.

[11] Shintani T, Hayakawa N, Hoshi M, Sumida M, Kurisu K, Oki S, et al. High incidence 
of meningioma among Hiroshima atomic bomb survivors. J Radiat Res (Tokyo) 1999;40:49_ 57. doi:10.1269/jrr.40.49.

[12] Smoll NR, Brady Z, Scurrah K, Mathews JD. Exposure to ionizing radiation and brain cancer incidence: The Life Span Study cohort. Cancer Epidemiol 2016;42:60-5. doi:10.1016/j.canep.2016.03.006.

[13] Preston DL, Ron E, Yonehara S, Kobuke T, Fujii H, Kishikawa M, et al. Tumors of the Nervous System and Pituitary Gland Associated With Atomic Bomb Radiation Exposure. JNCI J Natl Cancer Inst 2002;94:1555-63. doi:10.1093/jnci/94.20.1555.

[14] Bartsch H. N-nitroso compounds and human cancer: where do we stand? IARC Sci Publ 1991:1-10.

[15] Lijinsky W. N-Nitroso compounds in the diet. Mutat Res 1999;443:129-38.

[16] Rice JM, Rehm S, Donovan PJ, Perantoni AO. Comparative transplacental carcinogenesis by directly acting and metabolism-dependent alkylating agents in rodents and nonhuman primates. IARC Sci Publ 1989:17-34.

[17] Kyrtopoulos SA. N-nitroso compound formation in human gastric juice. Cancer Surv 1989;8:423-42.

[18] IARC Working Group on the Evaluation of Carcinogenic Risk to Humans. Red Meat and Processed Meat. Lyon (FR): International Agency for Research on Cancer; 2018.

[19] Dietrich M, Block G, Pogoda JM, Buffler P, Hecht S, Preston-Martin S. A review: dietary and endogenously formed N-nitroso compounds and risk of childhood brain tumors. Cancer Causes Control CCC 2005;16:619-35. doi:10.1007/s10552-005-0168-y.

[20] Huncharek M, Kupelnick B. A meta-analysis of maternal cured meat consumption during pregnancy and the risk of childhood brain tumors. Neuroepidemiology 2004;23:78-84. doi:10.1159/000073979.

[21] Pogoda JM, Preston-Martin S, Howe G, Lubin F, Mueller BA, Holly EA, et al. An international case-control study of maternal diet during pregnancy and childhood brain tumor risk: a histology-specific analysis by food group. Ann Epidemiol 2009;19:148-60. doi:10.1016/j.annepidem.2008.12.011.

[22] Blowers L, Preston-Martin S, Mack WJ. Dietary and other lifestyle factors of women with brain gliomas in Los Angeles County (California, USA). Cancer Causes Control CCC 1997;8:5-12.

[23] Lee M, Wrensch M, Miike R. Dietary and tobacco risk factors for adult onset glioma in the San Francisco Bay Area (California, USA). Cancer Causes Control CCC 1997;8:13-24. [24] Terry MB, Howe G, Pogoda JM, Zhang FF, Ahlbom A, Choi W, et al. An 
international case-control study of adult diet and brain tumor risk: a histology-specific analysis by food group. Ann Epidemiol 2009;19:161-71. doi:10.1016/j.annepidem.2008.12.010.

[25] Michaud DS, Holick CN, Batchelor TT, Giovannucci E, Hunter DJ. Prospective study of meat intake and dietary nitrates, nitrites, and nitrosamines and risk of adult glioma. Am J Clin Nutr 2009;90:570-7. doi:10.3945/ajen.2008.27199.

[26] Dubrow R, Darefsky AS, Park Y, Mayne ST, Moore SC, Kilfoy B, et al. Dietary components related to $\mathrm{N}$-nitroso compound formation: a prospective study of adult glioma. Cancer Epidemiol Biomark Prev Publ Am Assoc Cancer Res Cosponsored Am Soc Prev Oncol 2010;19:1709-22. doi:10.1158/1055-9965.EPI-10-0225.

[27] La Vecchia C, Franceschi S. Nutrition and gastric cancer. Can J Gastroenterol J Can Gastroenterol 2000;14 Suppl D:51D-54D. doi:10.1155/2000/869862.

[28] Neugut AI, Hayek M, Howe G. Epidemiology of gastric cancer. Semin Oncol 1996;23:281-91.

[29] Preston-Martin S, Mack W. Gliomas and meningiomas in men in Los Angeles County: investigation of exposures to N-nitroso compounds. IARC Sci Publ 1991:197-203.

[30] Acquavella J, Olsen G, Cole P, Ireland B, Kaneene J, Schuman S, et al. Cancer among farmers: a meta-analysis. Ann Epidemiol 1998;8:64-74.

[31] Khuder SA, Mutgi AB, Schaub EA. Meta-analyses of brain cancer and farming. Am J Ind Med 1998;34:252-60.

[32] Fallahi P, Foddis R, Cristaudo A, Antonelli A. High risk of brain tumors in farmers: a mini-review of the literature, and report of the results of a case control study. Clin Ter 2017;168:e290-2. doi:10.7417/T.2017.2022.

[33] Piel C, Pouchieu C, Migault L, Béziat B, Boulanger M, Bureau M, et al. Increased risk of central nervous system tumours with carbamate insecticide use in the prospective cohort AGRICAN. Int J Epidemiol 2018. doi:10.1093/ije/dyy246.

[34] Samanic CM, De Roos AJ, Stewart PA, Rajaraman P, Waters MA, Inskip PD. Occupational exposure to pesticides and risk of adult brain tumors. Am $\mathrm{J}$ Epidemiol 2008;167:976-85. doi:10.1093/aje/kwm401.

[35] Piel C, Pouchieu C, Tual S, Migault L, Lemarchand C, Carles C, et al. Central nervous system tumors and agricultural exposures in the prospective cohort AGRICAN. Int J Cancer 2017;141:1771-82. doi:10.1002/ijc.30879.

[36] Ruder AM, Waters MA, Carreón T, Butler MA, Davis-King KE, Calvert GM, et al. The Upper Midwest Health Study: a case-control study of primary intracranial gliomas in 
farm and rural residents. J Agric Saf Health 2006;12:255-74.

[37] Provost D, Cantagrel A, Lebailly P, Jaffré A, Loyant V, Loiseau H, et al. Brain tumours and exposure to pesticides: a case-control study in southwestern France. Occup Environ Med 2007;64:509-14. doi:10.1136/oem.2006.028100.

[38] Carles C, Bouvier G, Esquirol Y, Piel C, Migault L, Pouchieu C, et al. Residential proximity to agricultural land and risk of brain tumor in the general population. Environ Res 2017;159:321-30. doi:10.1016/j.envres.2017.08.025.

[39] Van Maele-Fabry G, Hoet P, Lison D. Parental occupational exposure to pesticides as risk factor for brain tumors in children and young adults: a systematic review and metaanalysis. Environ Int 2013;56:19-31. doi:10.1016/j.envint.2013.02.011.

[40] Van Maele-Fabry G, Gamet-Payrastre L, Lison D. Residential exposure to pesticides as risk factor for childhood and young adult brain tumors: A systematic review and metaanalysis. Environ Int 2017;106:69-90. doi:10.1016/j.envint.2017.05.018.

[41] Vidart d'Egurbide Bagazgoïtia N, Bailey HD, Orsi L, Lacour B, Guerrini-Rousseau L, Bertozzi A-I, et al. Maternal residential pesticide use during pregnancy and risk of malignant childhood brain tumors: A pooled analysis of the ESCALE and ESTELLE studies (SFCE). Int J Cancer 2018;142:489-97. doi:10.1002/ijc.31073.

[42] Patel DM, Jones RR, Booth BJ, Olsson AC, Kromhout H, Straif K, et al. Parental occupational exposure to pesticides, animals and organic dust and risk of childhood leukemia and central nervous system tumors: Findings from the International Childhood Cancer Cohort Consortium (I4C). Int J Cancer 2019. doi:10.1002/ijc.32388.

[43] Molina MJ, Molina LT. Megacities and Atmospheric Pollution. J Air Waste Manag Assoc 2004;54:644-80. doi:10.1080/10473289.2004.10470936.

[44] Bruce N, Perez-Padilla R, Albalak R. Indoor air pollution in developing countries: a major environmental and public health challenge. Bull World Health Organ 2000;78:107892.

[45] Loomis D, Grosse Y, Lauby-Secretan B, El Ghissassi F, Bouvard V, BenbrahimTallaa L, et al. The carcinogenicity of outdoor air pollution. Lancet Oncol 2013;14:1262-3.

[46] Hong Y-C, Lee J-T, Kim H, Kwon H-J. Air pollution: a new risk factor in ischemic stroke mortality. Stroke 2002;33:2165-9.

[47] Lisabeth L, Escobar J, Dvonch J, Sanchez B, Majersik J, Brown D, et al. Ambient air pollution and risk of ischemic stroke and TIA. Ann Neurol 2008;64:53-9. doi:10.1002/ana.21403.

[48] Lokken RP, Wellenius GA, Coull BA, Burger MR, Schlaug G, Suh HH, et al. Air 
Pollution and Risk of Stroke: Underestimation of Effect Due to Misclassification of Time of Event Onset. Epidemiol Camb Mass 2009;20:137-42.

[49] Finkelstein MM, Jerrett M. A study of the relationships between Parkinson's disease and markers of traffic-derived and environmental manganese air pollution in two Canadian cities. Environ Res 2007;104:420-32. doi:10.1016/j.envres.2007.03.002.

[50] Brook RD, Rajagopalan S, Pope CA, Brook JR, Bhatnagar A, Diez-Roux AV, et al. Particulate matter air pollution and cardiovascular disease: An update to the scientific statement from the American Heart Association. Circulation 2010;121:2331-78. doi:10.1161/CIR.0b013e3181dbece1.

[51] Block ML, Calderón-Garcidueñas L. Air pollution: mechanisms of neuroinflammation and CNS disease. Trends Neurosci 2009;32:506-16. doi:10.1016/j.tins.2009.05.009.

[52] Valberg PA, Long CM. Do brain cancer rates correlate with ambient exposure levels of criteria air pollutants or hazardous air pollutants (HAPs)? Air Qual Atmosphere Health 2012;5:115-23. doi:10.1007/s11869-010-0122-3.

[53] Boeglin ML, Wessels D, Henshel D. An investigation of the relationship between air emissions of volatile organic compounds and the incidence of cancer in Indiana counties. Environ Res 2006;100:242-54. doi:10.1016/j.envres.2005.04.004.

[54] Jørgensen JT, Johansen MS, Ravnskjær L, Andersen KK, Bräuner EV, Loft S, et al. Long-term exposure to ambient air pollution and incidence of brain tumours: The Danish Nurse Cohort. Neurotoxicology 2016;55:122-30. doi:10.1016/j.neuro.2016.06.003.

[55] Raaschou-Nielsen O, Andersen ZJ, Hvidberg M, Jensen SS, Ketzel M, Sørensen M, et al. Air pollution from traffic and cancer incidence: a Danish cohort study. Environ Health Glob Access Sci Source 2011;10:67. doi:10.1186/1476-069X-10-67.

[56] Calle EE, Peters JM, Henley J, Hannan L, Thurston GD, Thun MJ, et al. Ambient air pollution and brain cancer mortality. Cancer Causes Control CCC 2009;20:1645-51. doi:10.1007/s10552-009-9412-1.

[57] Andersen ZJ, Pedersen M, Weinmayr G, Stafoggia M, Galassi C, Jørgensen JT, et al. Long-term exposure to ambient air pollution and incidence of brain tumor: the European Study of Cohorts for Air Pollution Effects (ESCAPE). Neuro-Oncol 2018;20:420-32. doi:10.1093/neuonc/nox163.

[58] Poulsen AH, Sørensen M, Andersen ZJ, Ketzel M, Raaschou-Nielsen O. Air pollution from traffic and risk for brain tumors: a nationwide study in Denmark. Cancer Causes Control CCC 2016;27:473-80. doi:10.1007/s10552-016-0721-x.

[59] Heusinkveld HJ, Wahle T, Campbell A, Westerink RHS, Tran L, Johnston H, et al. 
Neurodegenerative and neurological disorders by small inhaled particles. Neurotoxicology 2016;56:94-106. doi:10.1016/j.neuro.2016.07.007.

[60] Maher BA, Ahmed IAM, Karloukovski V, MacLaren DA, Foulds PG, Allsop D, et al. Magnetite pollution nanoparticles in the human brain. Proc Natl Acad Sci 2016;113:10797801. doi:10.1073/pnas.1605941113.

[61] Sowers JL, Johnson KM, Conrad C, Patterson JT, Sowers LC. The role of inflammation in brain cancer. Adv Exp Med Biol 2014;816:75-105. doi:10.1007/978-3-03480837-8_4.

[62] McKean-Cowdin R, Calle EE, Peters JM, Henley J, Hannan L, Thurston GD, et al. Ambient air pollution and brain cancer mortality. Cancer Causes Control CCC 2009;20:164551. doi:10.1007/s10552-009-9412-1.

[63] Brenner AV, Linet MS, Fine HA, Shapiro WR, Selker RG, Black PM, et al. History of allergies and autoimmune diseases and risk of brain tumors in adults. Int $\mathrm{J}$ Cancer 2002;99:252-9. doi:10.1002/ijc.10320.

[64] Wiemels JL, Wiencke JK, Sison JD, Miike R, McMillan A, Wrensch M. History of allergies among adults with glioma and controls. Int J Cancer 2002;98:609-15.

[65] Schwartzbaum J, Jonsson F, Ahlbom A, Preston-Martin S, Lönn S, Söderberg KC, et al. Cohort studies of association between self-reported allergic conditions, immune-related diagnoses and glioma and meningioma risk. Int $J$ Cancer 2003;106:423-8. doi:10.1002/ijc.11230.

[66] Cahoon EK, Inskip PD, Gridley G, Brenner AV. Immune-related conditions and subsequent risk of brain cancer in a cohort of 4.5 million male US veterans. Br J Cancer 2014;110:1825-33. doi:10.1038/bjc.2014.97.

[67] Hwang C-Y, Chen Y-J, Lin M-W, Chen T-J, Chu S-Y, Chen C-C, et al. Cancer risk in patients with allergic rhinitis, asthma and atopic dermatitis: a nationwide cohort study in Taiwan. Int J Cancer 2012;130:1160-7. doi:10.1002/ijc.26105.

[68] Turner MC, Chen Y, Krewski D, Ghadirian P, Thun MJ, Calle EE. Cancer mortality among US men and women with asthma and hay fever. Am J Epidemiol 2005;162:212-21. doi:10.1093/aje/kwi193.

[69] Kim JH, Lee J-K, Kim H-G, Kim K-B, Kim HR. Possible Effects of Radiofrequency Electromagnetic Field Exposure on Central Nerve System. Biomol Ther 2019;27:265-75. doi:10.4062/biomolther.2018.152.

[70] Moulder JE, Erdreich LS, Malyapa RS, Merritt J, Pickard WF, Vijayalaxmi null. Cell phones and cancer: what is the evidence for a connection? Radiat Res 1999;151:513-31. 
[71] Ertilav K, Uslusoy F, Ataizi S, Nazıroğlu M. Long term exposure to cell phone frequencies (900 and $1800 \mathrm{MHz}$ ) induces apoptosis, mitochondrial oxidative stress and TRPV1 channel activation in the hippocampus and dorsal root ganglion of rats. Metab Brain Dis 2018;33:753-63. doi:10.1007/s11011-017-0180-4.

[72] Hossmann K-A, Hermann DM. Effects of electromagnetic radiation of mobile phones on the central nervous system. Bioelectromagnetics 2003;24:49-62. doi:10.1002/bem.10068.

[73] Jiang D-P, Li J-H, Zhang J, Xu S-L, Kuang F, Lang H-Y, et al. Long-term electromagnetic pulse exposure induces Abeta deposition and cognitive dysfunction through oxidative stress and overexpression of APP and BACE1. Brain Res 2016;1642:10-9. doi:10.1016/j.brainres.2016.02.053.

[74] Kleinlogel H, Dierks T, Koenig T, Lehmann H, Minder A, Berz R. Effects of weak mobile phone - electromagnetic fields (GSM, UMTS) on event related potentials and cognitive functions. Bioelectromagnetics 2008;29:488-97. doi:10.1002/bem.20418.

[75] Jeong YJ, Kang G-Y, Kwon JH, Choi H-D, Pack J-K, Kim N, et al. $1950 \mathrm{MHz}$ Electromagnetic Fields Ameliorate $A \beta$ Pathology in Alzheimer's Disease Mice. Curr Alzheimer Res 2015;12:481-92.

[76] Wyde ME, Horn TL, Capstick MH, Ladbury JM, Koepke G, Wilson PF, et al. Effect of cell phone radiofrequency radiation on body temperature in rodents: Pilot studies of the National Toxicology Program's reverberation chamber exposure system. Bioelectromagnetics 2018;39:190-9. doi:10.1002/bem.22116.

[77] Wainwright P. Thermal effects of radiation from cellular telephones. Phys Med Biol 2000;45:2363-72.

[78] INTERPHONE Study Group. Brain tumour risk in relation to mobile telephone use: results of the INTERPHONE international case-control study. Int J Epidemiol 2010;39:67594. doi:10.1093/ije/dyq079.

[79] Momoli F, Siemiatycki J, McBride ML, Parent M-É, Richardson L, Bedard D, et al. Probabilistic Multiple-Bias Modeling Applied to the Canadian Data From the Interphone Study of Mobile Phone Use and Risk of Glioma, Meningioma, Acoustic Neuroma, and Parotid Gland Tumors. Am J Epidemiol 2017;186:885-93. doi:10.1093/aje/kwx157.

[80] Bortkiewicz A, Gadzicka E, Szymczak W. Mobile phone use and risk for intracranial tumors and salivary gland tumors - A meta-analysis. Int J Occup Med Environ Health 2017;30:27-43. doi:10.13075/ijomeh.1896.00802.

[81] Yang M, Guo W, Yang C, Tang J, Huang Q, Feng S, et al. Mobile phone use and glioma risk: A systematic review and meta-analysis. PloS One 2017;12:e0175136. 
doi:10.1371/journal.pone.0175136.

[82] Cardis E, Deltour I, Mann S, Moissonnier M, Taki M, Varsier N, et al. Distribution of RF energy emitted by mobile phones in anatomical structures of the brain. Phys Med Biol 2008;53:2771-83. doi:10.1088/0031-9155/53/11/001.

[83] Dimbylow PJ, Mann SM. SAR calculations in an anatomically realistic model of the head for mobile communication transceivers at $900 \mathrm{MHz}$ and $1.8 \mathrm{GHz}$. Phys Med Biol 1994;39:1537-53.

[84] Hardell L, Carlberg M, Söderqvist F, Mild KH. Case-control study of the association between malignant brain tumours diagnosed between 2007 and 2009 and mobile and cordless phone use. Int J Oncol 2013;43:1833-45. doi:10.3892/ijo.2013.2111.

[85] Lahkola A, Auvinen A, Raitanen J, Schoemaker MJ, Christensen HC, Feychting M, et al. Mobile phone use and risk of glioma in 5 North European countries. Int $\mathrm{J}$ Cancer 2007;120:1769-75. doi:10.1002/ijc.22503.

[86] Hardell L, Carlberg M. Using the Hill viewpoints from 1965 for evaluating strengths of evidence of the risk for brain tumors associated with use of mobile and cordless phones. Rev Environ Health 2013;28:97-106. doi:10.1515/reveh-2013-0006.

[87] Gale BD, Juran D. Cellular telephones and risk for brain tumors: a population-based, $\begin{array}{llll}\text { incident } \quad \text { case-control } \quad \text { study. } & \text { Neurology }\end{array}$ doi:10.1212/01.wnl.0000205131.20290.46.

[88] Benson VS, Pirie K, Schüz J, Reeves GK, Beral V, Green J, et al. Mobile phone use and risk of brain neoplasms and other cancers: prospective study. Int $\mathrm{J}$ Epidemiol 2013;42:792-802. doi:10.1093/ije/dyt072.

[89] Persson T, Törnevik C, Larsson L-E, Lovén J. Output power distributions of terminals in a 3G mobile communication network. Bioelectromagnetics 2012;33:320-5. doi:10.1002/bem.20710.

[90] Gati A, Hadjem A, Wong M, Wiart J. Exposure induced by WCDMA mobiles phones in operating networks. IEEE Trans Wirel Commun 2009;8:5723-7. doi:10.1109/TWC.2009.12.080758.

[91] Langer CE, de Llobet P, Dalmau A, Wiart J, Goedhart G, Hours M, et al. Patterns of cellular phone use among young people in 12 countries: Implications for RF exposure. Environ Int 2017;107:65-74. doi:10.1016/j.envint.2017.06.002.

[92] Coureau G, Bouvier G, Lebailly P, Fabbro-Peray P, Gruber A, Leffondre K, et al. Mobile phone use and brain tumours in the CERENAT case-control study. Occup Environ Med 2014;71:514-22. doi:10.1136/oemed-2013-101754. 
[93] Hardell L, Mild KH, Carlberg M, Hallquist A. Cellular and cordless telephone use and the association with brain tumors in different age groups. Arch Environ Health 2004;59:1327. doi:10.3200/AEOH.59.3.132-137.

[94] Hardell L, Mild KH, Carlberg M, Söderqvist F. Tumour risk associated with use of cellular telephones or cordless desktop telephones. World J Surg Oncol 2006;4:74. doi:10.1186/1477-7819-4-74.

[95] Hansson Mild K, Carlberg M, Wilén J, Hardell L. How to combine the use of different mobile and cordless telephones in epidemiological studies on brain tumours? Eur J Cancer Prev Off J Eur Cancer Prev Organ ECP 2005;14:285-8.

[96] Morgan LL, Miller AB, Sasco A, Davis DL. Mobile phone radiation causes brain tumors and should be classified as a probable human carcinogen (2A) (review). Int J Oncol 2015;46:1865-71. doi:10.3892/ijo.2015.2908.

[97] Hardell L, Carlberg M, Söderqvist F, Hansson Mild K. Meta-analysis of long-term mobile phone use and the association with brain tumours. Int J Oncol 2008;32:1097-103.

[98] Hardell L, Carlberg M, Söderqvist F, Mild KH, Morgan LL. Long-term use of cellular phones and brain tumours: increased risk associated with use for $\geqslant 10$ years. Occup Environ Med 2007;64:626-32. doi:10.1136/oem.2006.029751.

[99] Ahlbom A, Green A, Kheifets L, Savitz D, Swerdlow A, ICNIRP (International Commission for Non-Ionizing Radiation Protection) Standing Committee on Epidemiology. Epidemiology of health effects of radiofrequency exposure. Environ Health Perspect 2004;112:1741-54. doi:10.1289/ehp.7306.

[100] Lagorio S, Röösli M. Mobile phone use and risk of intracranial tumors: a consistency analysis. Bioelectromagnetics 2014;35:79-90. doi:10.1002/bem.21829.

[101] Swerdlow AJ, Feychting M, Green AC, Leeka Kheifets LK, Savitz DA, International Commission for Non-Ionizing Radiation Protection Standing Committee on Epidemiology. Mobile phones, brain tumors, and the interphone study: where are we now? Environ Health Perspect 2011;119:1534-8. doi:10.1289/ehp.1103693.

[102] IARC. IARC classifies Radiofrequency Electromagnetic Fields as possibly carcinogenic to humans 2011:6.

[103] Mornet E, Kania R, Sauvaget E, Herman P, Tran Ba Huy P. Vestibular schwannoma and cell-phones. Results, limits and perspectives of clinical studies. Eur Ann Otorhinolaryngol Head Neck Dis 2013;130:275-82. doi:10.1016/j.anorl.2012.05.005.

[104] IARC Monographs on the Evaluation of Carcinogenic Risks to Humans - IARC n.d. https://monographs.iarc.fr/iarc-monographs-on-the-evaluation-of-carcinogenic-risks-to- 
humans-14/ (accessed May 27, 2019).

[105] Miller AB, Morgan LL, Udasin I, Davis DL. Cancer epidemiology update, following the 2011 IARC evaluation of radiofrequency electromagnetic fields (Monograph 102). Environ Res 2018;167:673-83. doi:10.1016/j.envres.2018.06.043. 


\section{$\underline{\text { Tables }}$}

Table 1 - Characteristics of recent studies evaluating the association between N-nitroso compounds and brain tumor

\begin{tabular}{|c|c|c|c|c|c|c|c|}
\hline Authors & Type of study & Country & Evaluation & $\begin{array}{l}\text { Participants } \\
\text { (cases) }\end{array}$ & $\begin{array}{l}\text { Type of } \\
\text { tumor }\end{array}$ & Type of food & Results \\
\hline $\begin{array}{l}\text { Michaud et } \\
\text { al. } 2009\end{array}$ & $\begin{array}{l}\text { Prospectve } \\
\text { cohort }\end{array}$ & $\begin{array}{l}\text { United } \\
\text { States }\end{array}$ & $\begin{array}{l}\text { Consumption of } \\
\text { red/processed meats and } \\
\text { risk of glioma }\end{array}$ & $289915(335)$ & Glioma & $\begin{array}{l}\text { Red meat, processed meat, } \\
\text { bacon, hot dog }\end{array}$ & $\begin{array}{l}\text { Negative } \\
\text { RR } 0.92,95 \% \text { CI } 0.48-1.77 \text { ) }\end{array}$ \\
\hline $\begin{array}{l}\text { Dubrow et } \\
\text { al. } 2010\end{array}$ & $\begin{array}{l}\text { Prospectve } \\
\text { cohort }\end{array}$ & $\begin{array}{l}\text { United } \\
\text { States }\end{array}$ & $\begin{array}{l}\text { Red/processed meat } \\
\text { consumption and risk of } \\
\text { glioma }\end{array}$ & $545770(585)$ & Glioma & Red meat, processed meat & $\begin{array}{l}\text { Negative } \\
\text { RR } 1.05(0.80-1.37) \text { for processed meat } \\
0.85(0.65-1.11) \text { for red meat }\end{array}$ \\
\hline $\begin{array}{l}\text { Pogoda, } \\
2009\end{array}$ & Case-control & $\begin{array}{l}\text { International } \\
7 \text { countries }\end{array}$ & $\begin{array}{l}\text { Maternal diet during } \\
\text { pregnancy and risk of } \\
\text { childhood brain tumors }\end{array}$ & $34441(1218)$ & $\begin{array}{l}\text { All brain } \\
\text { tumors }\end{array}$ & $\begin{array}{l}\text { Foods high in nitrates } \\
\text { and/or nitrites }\end{array}$ & $\begin{array}{l}\text { Positive particularly for astrocytomas } \\
\text { OR (1.8-2.5), } \mathbf{p} \leq \mathbf{0 . 0 3}\end{array}$ \\
\hline $\begin{array}{l}\text { Terry et al. } \\
2009\end{array}$ & Case-control & $\begin{array}{l}\text { International } \\
6 \text { countries }\end{array}$ & $\begin{array}{l}\text { Cured meat } \\
\text { consumption and risk of } \\
\text { glioma }\end{array}$ & $3671(1185)$ & $\begin{array}{l}\text { All brain } \\
\text { tumors }\end{array}$ & $\begin{array}{l}\text { Food groups including } \\
\text { cured meats }\end{array}$ & $\begin{array}{l}\text { Negative } \\
\text { RR } 0.9(0.7-1.2)\end{array}$ \\
\hline
\end{tabular}

RR, relative risk; OR, odds ratio. Significant ORs are in bold type. 
Table 2 - Characteristics of recent studies evaluating the association between pesticides and brain tumor.

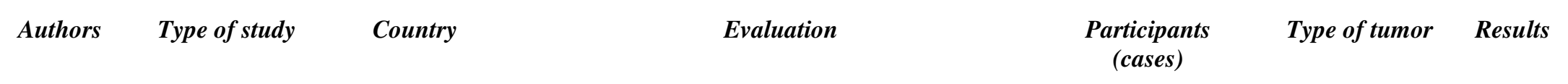

\begin{tabular}{|c|c|c|c|c|c|c|}
\hline \multicolumn{7}{|c|}{ Risk of adult brain tumors exposure of pesticides } \\
\hline Piel, 2017 & Prospective & French & $\begin{array}{l}\text { Exposure of farmers and pesticide users and the } \\
\text { incidence of CNS tumors }\end{array}$ & $181842(273)$ & $\begin{array}{l}\text { Gliomas and } \\
\text { meningiomas }\end{array}$ & Positive (HR 1.96; $95 \%$ 1.11-3.47) \\
\hline Piel 2018 & Prospective & French & $\begin{array}{l}\text { Potential exposure to carbamate insecticides and the } \\
\text { incidence of CNS tumors }\end{array}$ & $\begin{array}{l}181842 \text { ( } 381 \\
\text { incident cases) }\end{array}$ & All brain tumors & Positive \\
\hline Fallahi, 2017 & Case-control & Italy & Risk for brain tumors and rural activity & $696(174)$ & $\begin{array}{l}\text { Gliomas and } \\
\text { meningiomas }\end{array}$ & Positive \\
\hline Carles 2017 & Case-control & French & $\begin{array}{l}\text { Residential proximity to agricultural land and risk } \\
\text { of brain tumor in the general population }\end{array}$ & $1470(490)$ & $\begin{array}{l}\text { Gliomas and } \\
\text { meningiomas }\end{array}$ & $\begin{array}{l}\text { Positive (OR } 2.3095 \% \text { CI 1.04-5.10) } \\
\text { for meningioma and proximity to open } \\
\text { field crops, negative for glioma and } \\
\text { proximity to agricultural land }\end{array}$ \\
\hline $\begin{array}{l}\text { Samanic, } \\
\quad 2008\end{array}$ & Case-control & United States & $\begin{array}{l}\text { Occupational exposure to insecticides and } \\
\text { herbicides and risk of glioma and meningioma }\end{array}$ & $1422(657)$ & $\begin{array}{l}\text { Gliomas and } \\
\text { meningiomas }\end{array}$ & $\begin{array}{l}\text { Negative for glioma and exposure to } \\
\text { insecticides or herbicides } \\
\text { Positive (OR 2.4, 95\% 1.4-4.3) for } \\
\text { meningioma and women who used } \\
\text { herbicides }\end{array}$ \\
\hline Provost 2007 & Case-control & France & $\begin{array}{l}\text { Exposure to pesticides and risk of brain tumor in } \\
\text { adults }\end{array}$ & $663(221)$ & All brain tumors & $\begin{array}{l}\text { Negative except in the highest quartile of } \\
\text { the cumulative index, a significant } \\
\text { association was found for brain tumors } \\
\text { (OR 2.16, 95\% CI 1.10-4.23) and for } \\
\text { gliomas (OR 3.21, 95\% CI 1.13-9.11) } \\
\text { but not meningiomas. }\end{array}$ \\
\hline Ruder, 2006 & Case-control & United States & $\begin{array}{l}\text { Intracranial glioma in the non-metropolitan } \\
\text { population }\end{array}$ & $1973(798)$ & All brain tumors & $\begin{array}{l}\text { Farm or rural residence and summary } \\
\text { farm exposure associated with decreased } \\
\text { glioma risk }\end{array}$ \\
\hline
\end{tabular}




\begin{tabular}{|c|c|c|c|c|c|c|}
\hline Lee, 2005 & Case-control & US & Adult glioma and risk of agricultural pesticide use & $749(251)$ & All brain tumous & $\begin{array}{l}\text { Positive for men ever living or working } \\
\text { on a farm and duration of farming and } \\
\text { glioma ( } \geq 55 \text { years on a farm; OR 3.9, } \\
\text { 95\% CI 1.8-8.6) }\end{array}$ \\
\hline \multicolumn{7}{|c|}{ Risk of childhood brain tumors and parental exposure of pesticides } \\
\hline Patel, 2019 & Prospective & International & $\begin{array}{l}\text { Parental occupational exposure and risk of } \\
\text { childhood CNS tumors }\end{array}$ & $329658(158)$ & All brain tumors & Negative \\
\hline Vidart, 2018 & $\begin{array}{l}\text { A pooled } \\
\text { analysis of } 2 \\
\text { case-control } \\
\text { studies }\end{array}$ & French & $\begin{array}{l}\text { Maternal residential pesticide use during pregnancy } \\
\text { and risk of malignant childhood brain tumors }\end{array}$ & $3539(437)$ & All brain tumors & $\begin{array}{l}\text { Positive } \\
\text { (OR 1.4, 95\% CI 1.2-1.8) } \\
\text { and, more specifically, with insecticides } \\
(\text { OR 1.4, 1.2-1.8) }\end{array}$ \\
\hline Febvey 2016 & Case-control & European & $\begin{array}{l}\text { CNS tumors in children and related to parental } \\
\text { occupational pesticide exposures }\end{array}$ & $6859(1361)$ & All brain tumors & Negative (OR 0.76, 95\% CI 0.41-1.41) \\
\hline Greenop 2013 & Case-control & australian & $\begin{array}{l}\text { Exposure to pesticides before pregnancy, during } \\
\text { pregnancy and during childhood and risk of brain } \\
\text { tumor. }\end{array}$ & $1698(335)$ & All brain tumors & $\begin{array}{l}\text { Positive association between home } \\
\text { pesticide use in the year before } \\
\text { pregnancy and the risk of childhood } \\
\text { brain tumor (OR 1.90, 95\% CI 1.08- } \\
\text { 3.36) }\end{array}$ \\
\hline $\mathrm{CNS}$ & central ner & system; & odds ratio; $\mathrm{HR}$, hazard raio; $95 \% \mathrm{CI}$, & $95 \%$ confid & interval. & ant ORs are in bold type. \\
\hline
\end{tabular}


Table 3 - Characteristics of meta-analysis evaluating the association between air-pollution and brain tumor incidence or mortality

\begin{tabular}{|c|c|c|c|c|c|c|c|c|}
\hline Authors & Journal & Study type & Tumor type & Country & Population & Pollutants & Analysis method & Results \\
\hline $\begin{array}{c}\text { Andersen } \\
2018\end{array}$ & Neuro-Oncology & $\begin{array}{l}\text { Prospectve } \\
\text { cohort (12 years } \\
\text { of follow-up) }\end{array}$ & $\begin{array}{l}\text { malignant brain } \\
\text { tumor, non } \\
\text { malignant brain } \\
\text { tumor }\end{array}$ & $\begin{array}{l}12 \text { cohorts } \\
\text { from } 6 \\
\text { European } \\
\text { countries }\end{array}$ & $\begin{array}{l}\text { - malignant brain } \\
\text { tumors: } 282194 \\
\text { participants, from } \\
\text { which } 466 \\
\text { developed } \\
\text { malignant brain } \\
\text { tumors } \\
\text { - malignant and } \\
\text { non malignant } \\
\text { brain tumors: } 106 \\
786 \text { participants, } \\
\text { from which } 176 \\
\text { developed non } \\
\text { malignant and } \\
\text { 190 developed } \\
\text { malignant brain } \\
\text { tumors }\end{array}$ & $\begin{array}{l}\text { annual average concentrations of: } \\
\text { - nitrogen dioxide, nitrogen oxides, } \\
\mathrm{PM}_{2.5}, \mathrm{PM}_{10} \text { at baseline residence } \\
\text { for each participant (standardized } \\
\text { area-specific land-use regression } \\
\text { models) } \\
\text { - } 8 \text { elements in } \mathrm{PM}_{2.5} \text { and } \mathrm{PM}_{10} \\
\text { (copper, iron, zinc, sulfur, nickel, } \\
\text { vanadium, silicon and potassium) } \\
\text { - traffic intensity }\end{array}$ & $\begin{array}{l}\text { - cohort specific analysis: } \\
\text { association between each } \\
\text { pollutant absorbance and } \\
\text { brain tumor (malignant, } \\
\text { non malignant, total) in } \\
\text { each cohort } \\
\text { - meta-analysis: } \\
\text { combination of the } \\
\text { estimates from each } \\
\text { cohort, for each pollutant } \\
\text { and each brain tumor } \\
\text { subtype }\end{array}$ & $\begin{array}{l}\text { - association between traffic-related } \mathrm{PM}_{2.5} \\
\text { absorbance and malignant brain tumors } \\
\text { - no association with overall or nonmalignant } \\
\text { brain tumors }\end{array}$ \\
\hline $\begin{array}{l}\text { Boeglin } \\
2006\end{array}$ & $\begin{array}{l}\text { Environmental } \\
\text { Research }\end{array}$ & $\begin{array}{l}\text { retrospective } \\
\text { epidemiological }\end{array}$ & $\begin{array}{l}\text { nervous system } \\
\text { cancer }\end{array}$ & $\begin{array}{l}\text { Indiana } \\
\text { (United } \\
\text { States) }\end{array}$ & 92 counties & $\begin{array}{l}\text { release of volatile organic } \\
\text { compounds } 8 \text { years prior to cancer } \\
\text { incidence (1988) }\end{array}$ & $\begin{array}{l}\text { relationship between the } \\
\text { amount of volatile organic } \\
\text { compounds released in } \\
\text { each county (Toxic } \\
\text { Release Inventory), and } \\
\text { the county-by-county } \\
\text { incidence of nervous } \\
\text { system cancer }\end{array}$ & $\begin{array}{l}\text { association with non chlorinated stack, total } \\
\text { stack and non chlorinated total of volatile } \\
\text { organic compounds }\end{array}$ \\
\hline $\begin{array}{l}\text { McKean- } \\
\text { Cowdin } \\
2009\end{array}$ & $\begin{array}{l}\text { Cancer Causes } \\
\text { Control }\end{array}$ & $\begin{array}{l}\text { Prospectve } \\
\text { cohort (18 years } \\
\text { of follow-up) }\end{array}$ & $\begin{array}{l}\text { nervous system } \\
\text { cancer }\end{array}$ & $\begin{array}{l}\text { United } \\
\text { States }\end{array}$ & $\begin{array}{l}630487 \\
\text { participants, } 1 \\
284 \text { deaths due to } \\
\text { brain cancer }\end{array}$ & $\begin{array}{l}\text { follow-up duration average } \\
\text { concentrations of: } \mathrm{PM}_{2.5} \text { and } \mathrm{PM}_{10} \text {, } \\
\text { total suspended particles, sulfur } \\
\text { dioxide, nitrogen dioxide, carbon } \\
\text { monoxide, ozone }\end{array}$ & $\begin{array}{l}\text { hazard ratios for mortality } \\
\text { due to nervous system } \\
\text { cancer }\end{array}$ & $\begin{array}{l}\text { - no positive association between any listed } \\
\text { pollutant and nervous system cancer mortality } \\
\text { - small protective effect of sulfur dioxide, } \\
\text { nitrogen dioxide, carbon monoxide on } \\
\text { nervous system cancer mortality }\end{array}$ \\
\hline $\begin{array}{l}\text { Valberg } \\
2012\end{array}$ & $\begin{array}{l}\text { Air Qual Atmos } \\
\text { Health }\end{array}$ & $\begin{array}{l}\text { retrospective } \\
\text { epidemiological }\end{array}$ & $\begin{array}{l}\text { nervous system } \\
\text { cancer }\end{array}$ & $\begin{array}{l}\text { United } \\
\text { States }\end{array}$ & $\begin{array}{l}\text { brain cancer } \\
\text { incidence: } 875 \\
\text { counties } \\
\text { brain cancer } \\
\text { mortality: } 821 \\
\text { counties. }\end{array}$ & $\begin{array}{l}2008 \text { average concentrations of: } \\
\text { - PM, nitrogen dioxide, sulfur } \\
\text { dioxide, ozone, carbon monoxide } \\
\text { - } 30 \text { ambient air pollutants that } \\
\text { were either IARC Group } 1 \\
\text { carcinogens (e.g., arsenic, } \\
\text { beryllium, benzene, and vinyl } \\
\text { chloride), or compounds that have } \\
\text { been suggested as hypothetical } \\
\text { brain cancer risk factors }\end{array}$ & $\begin{array}{l}\text { Pearson product-moment } \\
\text { correlation coefficients } \\
\text { with brain cancer mortality } \\
\text { or brain cancer incidence }\end{array}$ & $\begin{array}{l}\text { - small positive association between ozone } \\
\text { and nervous system cancer incidence } \\
\text { - small protective effect of some pollutants on } \\
\text { nervous system cancer incidence }\end{array}$ \\
\hline $\begin{array}{l}\text { Raaschou- } \\
\text { Nielsen } \\
2011\end{array}$ & $\begin{array}{l}\text { Environmental } \\
\text { Health }\end{array}$ & $\begin{array}{l}\text { Prospectve } \\
\text { cohort (13 years } \\
\text { of follow-up) }\end{array}$ & brain cancer & Danemark & $\begin{array}{l}54304 \\
\text { participants }\end{array}$ & $\begin{array}{l}\text { - concentration of nitrogen oxides } \\
\text { - presence of a street with a traffic } \\
\text { density }>10,000 \text { vehicles per day } \\
\text { within } 50 \mathrm{~m} \text { of the residence } \\
\text { - total number of kilometers driven }\end{array}$ & $\begin{array}{l}\text { Pearson product-moment } \\
\text { correlation coefficients } \\
\text { with brain cancer } \\
\text { incidence }\end{array}$ & $\begin{array}{l}\text { - association between nitrogen oxide } \\
\text { concentration and brain cancer: } \\
\text { unadjusted: HR 2.28; 95\% CI 1.24-4.17 } \\
\text { adjusted: HR 2.28; 95\% CI 1.25-4.19 } \\
\text { - association between proximity to major }\end{array}$ \\
\hline
\end{tabular}




\begin{tabular}{|c|c|c|c|c|c|c|c|}
\hline & & & & & & $\begin{array}{l}\text { by vehicles within } 200 \mathrm{~m} \text { of the } \\
\text { residence each day. }\end{array}$ & \\
\hline
\end{tabular}

HR, hazard raio; 95\% CI, 95\% confidence interval. Significant HRs are in bold type.

PM: particulate matter; $\mathrm{PM}_{2.5}$ : $\mathrm{PM}$ with a diameter of less than 2.5 micrometers; $\mathrm{PM}_{10}$ : $\mathrm{PM}$ with a diameter of 2.5 to 10 micrometers. street $(<50 \mathrm{~m})$ and brain cancer:

CI: 1.07-3.34

adjusted: HR 1.89; 95\% CI 1.07-3.36

- no association between nitrogen oxides

concentration and brain tumors. Tendency for

elevated risk among subjects with average

lifetime nitrogen oxides concentration $\geq 80$

$\mathrm{ug} / \mathrm{m} 3$

- small association between nitrogen oxides

concentration and non-glioma tumors.

- weak positive associations of $\mathrm{PM}_{25}$ and

nitrogen dioxide with brain tumors incidence

- associations were strongest for tumors

located in the meninges and for benign

tumors

association of $\mathrm{PM}_{2.5}$ with brain tumors was significantly enhanced in obese women 
Table 4 - Characteristic of meta-analysis evaluating the relationship between mobile-phone use and brain tumor incidences

\begin{tabular}{|c|c|c|c|c|}
\hline Authors & Journal & $\begin{array}{c}\text { Number of } \\
\text { studies }\end{array}$ & Tumor type & Inclusion criteria \\
\hline Bortkiewicz 2017 & $\begin{array}{l}\text { Int J Occup Med } \\
\text { Environ Health }\end{array}$ & $\begin{array}{l}24 \text { case- } \\
\text { control }\end{array}$ & 26846 cases, 50013 controls & $\begin{array}{l}\text { - papers in English } \\
\text { - original, case-control peer-reviewed studies published till the end of March } 2014 \\
\text { - measures of association (odds ratio and confidence interval of the effect measured) } \\
\text { - data on individual exposure }\end{array}$ \\
\hline Gong 2014 & $\begin{array}{l}\text { Zhonghua Yi Xue Za } \\
\text { Zhi }\end{array}$ & $\begin{array}{l}\text { [article in } \\
\text { chinese] }\end{array}$ & [article in Chinese] & [article in chinese] \\
\hline Hardell 2008 & Int J Oncol & $\begin{array}{l}16 \text { case- } \\
\text { control }\end{array}$ & not given (one study without numbers) & $\begin{array}{l}\text { - case-control studies } \\
\text { other criteria not defined precisely }\end{array}$ \\
\hline Kan 2008 & J. Neurooncol. & 9 case-control & 5259 cases, 12074 controls & $\begin{array}{l}\text { - papers in English } \\
\text { - case-control studies } \\
\text { - sufficient data so that the crude odds ratios (ORs) could be derived } \\
\text { - data on individual exposure clearly defined and evaluated to minimize misclassification } \\
\text { exclusion: exposure other than cellular phones (e.g., cordless phones) }\end{array}$ \\
\hline Khurana 2009 & Surg Neurol & $\begin{array}{l}11 \text { case- } \\
\text { control }\end{array}$ & Not specified & $\begin{array}{l}\text { - publication in a peer-reviewed journal } \\
\text { - inclusion of participants using cell phones for } \geq 10 \text { years } \\
\text { - incorporation of a laterality analysis of long-term }(\geq 10 \text {-year }) \text { users. }\end{array}$ \\
\hline Lagorio 2014 & Bioelectromagnetics & $\begin{array}{l}29 \text { case- } \\
\text { control }\end{array}$ & Not specified & $\begin{array}{l}\text { - individuals as units of information (cohort, case- control) } \\
\text { - mobile phone use or as the exposure of interest } \\
\text { - providing incidence-based (as opposed to mortality-based) estimates of the relative risk (RR) of disease } \\
\text { among the exposed in the whole target population } \\
\text { - focusing on morphology-specific groups of neoplasms in homogenous age classes } \\
\text { - analyses based on comparable exposure metrics and categories } \\
\text { - single risk estimate per neoplasm and exposure category per independent study (or distinct pooled analysis) }\end{array}$ \\
\hline Lahkola 2006 & $\begin{array}{l}\text { Scand J Work } \\
\text { Environ Health }\end{array}$ & $\begin{array}{l}11 \text { case- } \\
\text { control } \\
1 \text { cohort }\end{array}$ & $\begin{array}{l}2780 \text { cases } \\
\text { gliomas: } 1352 \text { cases, } 339 \text { classified as exposed } \\
\text { meningiomas: } 527 \text { cases, } 149 \text { classified as } \\
\text { exposed } \\
\text { acoustic neuromas: } 605 \text { cases, } 167 \text { classified as } \\
\text { exposed }\end{array}$ & $\begin{array}{l}\text { - original publications } \\
\text { - case-control or cohort publications } \\
\text { - using individual exposure data } \\
\text { - reporting information needed for the estimation of confidence intervals (standard error or confidence interval } \\
\text { of the effect measure or the number of persons by exposure and outcome status) }\end{array}$ \\
\hline Myung 2009 & $\mathrm{JCO}$ & $\begin{array}{l}23 \text { case- } \\
\text { control }\end{array}$ & 12344 cases, 25572 controls & $\begin{array}{l}\text { - case-control studies } \\
\text { - reported outcome measures with adjusted odds ratios and } 95 \% \text { CIs, crude odds ratios and } 95 \% \text { CIs, or values } \\
\text { in cells of a } 2 \text { × } 2 \text { table (from which odds ratios could be calculated) }\end{array}$ \\
\hline Yang 2017 & Plos One & $\begin{array}{l}11 \text { case- } \\
\text { control }\end{array}$ & 6028 cases, 11488 controls & $\begin{array}{l}\text { - average weekly mobile phone use frequency and } \geq 6 \text { months of continuous use } \\
\text { - recorded side of head predominantly used } \\
\text { - reported glioma pathology } \\
\text { - reported sample size and odds ratios for case-control studies } \\
\text { - digital and/or mobile phone types } \\
\text { - the control group comprised healthy subjects; who are not regularly exposed to radiation from mobile } \\
\text { phones or other related sources of electromagnetic radiation } \\
\text { Exclusion criteria: } \\
\text { - tumor not classified and/or data related to glioma not extracted } \\
\text { - Insufficient follow-up time }\end{array}$ \\
\hline
\end{tabular}


Table 5 - Pooled odd-ratios in meta-analysis evaluating the association between mobile-phone use and brain tumor incidence.

\begin{tabular}{|c|c|c|c|c|c|c|c|c|c|c|c|c|}
\hline & & & & Bortkiewicz 2017 & Gong 2014 & Hardell 2008 & Kan 2008 & Khurana 2009 & Lagorio 2014 & Lahkola 2006 & Myung 2009 & Yang 2017 \\
\hline \multirow{24}{*}{ 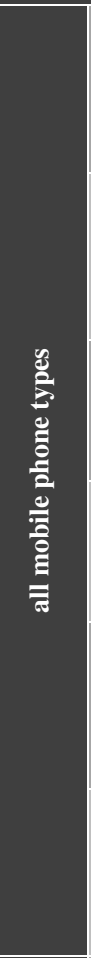 } & \multirow{4}{*}{ 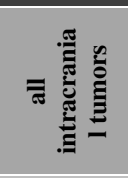 } & \multirow{2}{*}{ all use duration } & both sides & $0.94[0.86-1.03]$ & & - & $0.90[0.81-0.99]$ & - & $\begin{array}{l}\text { several analysis: } \\
\text { include } 1\end{array}$ & & $0.98[0.89-1.07]$ & - \\
\hline & & & ipsilateral & 1.29 [1.06-1.57] & - & - & - & - & - & - & - & - \\
\hline & & \multirow{2}{*}{ use $\geq 10$ years* } & both sides & $1.46[1.07-1.98]$ & - & - & $1.25[1.01-1.54]$ & $1.1[0.8-1.4]$ & - & 0.98 [0.83-1.16] & $1.18[1.04-1.34]$ & - \\
\hline & & & ipsilateral & - & - & - & - & $1.3[0.9-1.8]$ & - & 1.36 [0.99-1.87] & - & - \\
\hline & \multirow{4}{*}{ : } & \multirow[t]{2}{*}{ all use duration } & both sides & $0.92[0.83-1.03]$ & - & - & - & - & $\begin{array}{l}\text { several analysis: } \\
\text { include } 1\end{array}$ & & - & 0.98 [0.88-1.1] \\
\hline & & & ipsilateral & - & - & - & - & - & - & - & - & $0.97[0.88-1.06]$ \\
\hline & & \multirow{2}{*}{ use $\geq 10$ years* } & both sides & $1.46[1.07-1.98]$ & - & 1.2 [0.8-1.9] & - & - & - & 0.96 [0.78-1.18] & - & $1.44[1.08-1.91]$ \\
\hline & & & ipsilateral & - & $1.46[1.12,1.92]$ & $2.0[1.2-3.4]$ & - & $1.9[1.4-2.4]$ & - & $1.33[0.78-2.28]$ & - & $1.46[1.12-1.92]$ \\
\hline & \multirow{4}{*}{ 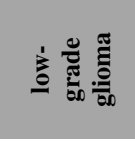 } & \multirow{2}{*}{ all use duration } & both sides & - & - & - & $1.14[0.91-1.43]$ & - & - & - & - & \\
\hline & & & ipsilateral & - & - & - & - & - & - & - & - & \\
\hline & & \multirow{2}{*}{ use $\geq 10$ years* } & both sides & - & - & - & - & - & - & - & - & I \\
\hline & & & ipsilateral & - & $2.27[1.81,2.85]$ & - & - & - & - & - & - & \\
\hline & \multirow{4}{*}{ 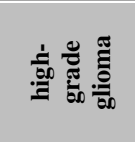 } & \multirow{2}{*}{ all use duration } & both sides & - & - & - & 0.86 [0.70-1.05] & - & - & - & - & - \\
\hline & & & ipsilateral & - & - & - & - & - & - & - & - & - \\
\hline & & \multirow{2}{*}{ use $\geq 10$ years* } & both sides & - & - & - & - & - & - & - & - & - \\
\hline & & & ipsilateral & - & - & - & - & - & - & - & - & - \\
\hline & \multirow{4}{*}{ 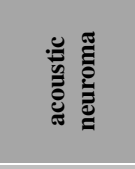 } & \multirow[t]{2}{*}{ all use duration } & both sides & $0.96[0.87-1.06]$ & - & $0.9[0.7-1.1]$ & $0.96[0.83-1.10]$ & - & $\begin{array}{l}\text { several analysis: } \\
\text { include } 1\end{array}$ & - & - & - \\
\hline & & & ipsilateral & - & - & - & - & - & - & - & - & - \\
\hline & & \multirow{2}{*}{ use $\geq 10$ years* } & both sides & - & - & $1.3[0.6-2.8]$ & - & - & - & 1.07 [0.89-1.30] & - & - \\
\hline & & & ipsilateral & - & - & $2.4[1.1-5.3]$ & - & $1.6[1.1-2.4]$ & - & $1.05[0.41-2.67]$ & - & - \\
\hline & \multirow{4}{*}{ 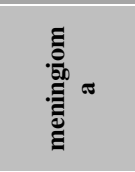 } & \multirow[t]{2}{*}{ all use duration } & both sides & $0.72[0.6-0.86]$ & - & $0.8[0.7-0.99]$ & $0.64[0.56-0.74]$ & - & $\begin{array}{l}\text { several analysis: } \\
\text { include } 1\end{array}$ & - & - & - \\
\hline & & & ipsilateral & - & - & - & - & - & - & - & - & - \\
\hline & & \multirow[b]{2}{*}{ use $\geq 10$ years* } & both sides & - & - & $1.3[0.9-1.8]$ & - & - & - & $0.87[0.72-1.05]$ & - & - \\
\hline & & & ipsilateral & - & - & $1.7[0.99-3.1]$ & - & $1.3[0.9-1.8]$ & - & 1.16 [0.82-1.63] & - & - \\
\hline \multirow{4}{*}{ 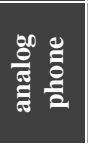 } & \multirow{4}{*}{ 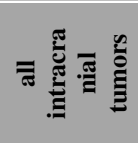 } & all use duration & both sides & $1.09[0.91-1.3]$ & - & - & $1.13[0.83-1.54]$ & - & - & 1.17 [0.91-1.49] & - & - \\
\hline & & air use tur ation & ipsilateral & - & - & - & - & - & - & - & - & - \\
\hline & & use $\geq 10$ years* & both sides & - & - & - & - & - & - & - & - & - \\
\hline & & & ipsilateral & - & - & - & - & - & - & - & - & - \\
\hline \multirow{4}{*}{ 焉比 } & \multirow{4}{*}{ 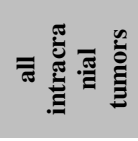 } & \multirow{2}{*}{ all use duration } & both sides & - & - & - & $0.86[0.68-1.09]$ & - & - & $1.04[0.80-1.35]$ & - & - \\
\hline & & & ipsilateral & - & - & - & - & - & - & - & - & - \\
\hline & & \multirow{2}{*}{ use $\geq 10$ years* } & both sides & - & - & - & - & - & - & - & - & - \\
\hline & & & ipsilateral & - & - & - & - & - & - & - & - & - \\
\hline
\end{tabular}

Data are ORs (95\% CIs). Significant ORs are in bold type.

* 5 years for Lakhola 2006 